\title{
The longevity of ceramic inlays (update)
}

\author{
Update privind longevitatea incrustaţiilor integral ceramice
}

Ana Maria Buruiană, Cornelia Bîcleşanu, Anamaria Florescu

Facultatea de Medicină dentară „Titu Maiorescu“, Bucureşti, România

\begin{abstract}
Ceramic inlays are the most currently used due to aesthetic and functional superiority.

Objectives. The aim of this study was to assess the longevity of ceramic inlays by looking at studies published over the past eight years.

Methods. A PubMed search was conducted to identify clinical studies on the longevity of ceramic inlays made from different types of ceramics, published over the last 8 years (2009-2017). The search was done by using the following keywords: "clinic performance", "dental ceramics", "inlays, onlays", with a total of 9 articles meeting the search criteria.

Results. There were studied 13092 ceramic inlays made of different types of ceramics and luted with dual-core resin cement which exhibit acceptable longevity for both the practician and the patient. The frequent cause of failure is fracture of restoration or dental tissue, with a notable difference between vital teeth and devital teeth, the latter presenting an increased risk of fracture compared to the former. There were no statistically significant differences in the different types of ceramic materials used.

Conclusions. Considering the results of the researched studies, it can be concluded that ceramic inlays and onlays, without making the difference between the type of the ceramic material used, exhibit acceptable longevity.
\end{abstract}

Keywords: clinic performance, dental ceramics, inlays

\begin{abstract}
REZUMAT
Incrustaţiile integral ceramice sunt cele mai utilizate în prezent, datorită superiorităţii estetice și funcționale. Scop. Obiectivul studiului a fost de a evalua longevitatea incrustaţiilor ceramice prin revizuirea studiilor publicate în ultimii 8 ani.

Material și metodă. A fost efectuată o căutare PubMed în vederea identificării studiilor clinice privind longevitatea inlay-urilor ceramice, realizate din diferite tipuri de ceramică, publicate în ultimii 8 ani (2009-2017). Căutarea s-a făcut prin folosirea unor cuvinte cheie - "clinical performance", "dental ceramics" "inlays, onlays" -, obţinându-se un total de 9 articole care au îndeplinit criteriile de căutare.

Rezultate. Studiile alese prezintă referiri asupra 13.092 de incrustaţii ceramice realizate din tipuri diferite de ceramică și cimentate cu material compozit cu priză duală, care prezintă o longevitate acceptabilă. Cauza frecventă a eșecului este reprezentată de fracturi ale restaurării sau ale ţesutului dentar remanent, cu o diferenţă notabilă între dinţii vitali și cei devitali. Nu s-au observat diferenţe semnificative din punct de vedere statistic, în ceea ce privește diferitele tipuri de materiale ceramice utilizate.

Concluzii. Având în vedere rezultatele studiilor cercetate, se poate concluziona faptul că inlay-urile ceramice, fără să facă diferenţa tipul ceramicii dentare utilizat, prezintă o longevitate acceptabilă.
\end{abstract}

Cuvinte cheie: incrustații ceramice, longevitate, performanţe clinice

\section{INTRODUCERE}

Deşi există metode de profilaxie uşor accesibile populaţiei, numeroşi pacienţi se prezintă în continuare în clinicile de medicină dentară solicitând tratamentul unor leziuni carioase extinse, Organi- zaţia Mondială a Sănătăţii (OMS) estimând prevalenţa cariei dentare ca fiind peste $90 \%$ în rândul adulţilor din întreaga lume $(1,2)$.

Alegerea manoperei terapeutice şi a materialelor de restaurare reprezintă o provocare pentru clinicieni, ţinând cont de oferta existentă în prezent. 
În ciuda faptului că studiile de cercetare demonstrează clar longevitatea şi integritatea superioară a incrustaţiilor din aur, cele integral ceramice sunt cele mai utilizate în prezent, datorită cererii pacienţilor pentru un aspect fizionomic.

Studiile arată că materialul ceramic are proprietăţi estetice, cum ar fi stabilitatea mare a culorii, biocompatibilitate bună şi rezistenţă ridicată (3).

În ceea ce priveşte comportamentul mecanic, materialul ideal de restaurare trebuie să fie similar cu ţesuturile dentare dure pe care le înlocuieşte. Smalţul, cu compoziţia sa unică în organism, formată din aproximativ 96\% substanţe minerale, 3\% apă şi $1 \%$ proteine, are o rezistenţă mare la uzură, dar este casant când nu e susţinut de dentină. Pe de altă parte, dentina este compusă din aproximativ $45 \%$ anorganic, $35 \%$ organic şi $20 \%$ apă în volum şi are un comportament complet diferit, din cauza rigidităţii considerabil mai reduse, cu diseminarea forţelor de-a lungul fibrelor de colagen.

Ultimele cercetări au demonstrat faptul că materialul ceramic este cel mai apropiat ca structură şi funcţionalitate de smalţul dentar, crescându-i astfel indicaţiile de utilizare (4).

Alături de aspect fizionomic şi restaurare funcţională, incrustaţia ceramică permite conservarea structurilor dentare şi oferă beneficiile tehnicilor adezive.

Din punct de vedere al compoziţiei, ceramica este formată din matrice de sticlă (sticlă încărcată cu particule), matrice de oxid de aluminiu sau matrice de zirconiu.

Ceramica dentară cu un conţinut ridicat de sticlă prezintă un grad ridicat de estetică, imitând cel mai bine proprietăţile fizionomice ale smalţului şi ale dentinei, iar ceramica având o rezistenţă mai mare este, în general, cristalină.

Producătorii folosesc cantităţi mici de particule de umplutură pentru a ghida efectele estetice precum opalescenţa, culoarea şi opacitatea. De asemenea, producătorii adaugă particule de umplutură la compoziţia de sticlă de bază pentru a îmbunătăţi proprietăţile mecanice precum rezistenţa şi conductibilitatea termică şi priza de contracţie $(5,6,7)$.

Ceramica dentară are însă şi dezavantaje reprezentate de prezenţa microporozităţilor la suprafaţa materialului, care apar în timpul procesului de sinterizare, ceea ce poate crea fisuri sau fracturi $(8,9$, $10)$.
De asemenea, pot apărea soluţii de continuitate, imposibilitatea/dificultatea finisării şi a lustruirii, uzura excesivă a dinţilor antagonişti (11).

\section{MATERIAL ŞI METODĂ}

A fost efectuată o căutare PubMed în vederea identificării studiilor clinice privind longevitatea inlay-urilor ceramice, realizate din diferite tipuri de ceramică, publicate în ultimii 8 ani (2009-2017). S-au folosit cuvintele cheie "clinical performances", "dental ceramics" "inlays, onlays".

\section{REZULTATE}

S-a obţinut un total de 9 studii care au îndeplinit criteriile de căutare. Acestea au fost realizate în SUA, Germania, Elveţia, Austria, Brazilia, Canada, Uruguay, Iran. În Tabelul 1 se găsesc detaliile celor 5 studii incluse în cercetare.

Spitznagel F.A. şi colaboratorii au condus un studiu clinic, ce a urmărit comportamentul incrustaţiilor realizate din ceramică duală (infiltrată cu polimer), efectuate utilizând sistemul CAD/CAM. $\mathrm{Au}$ fost realizate, în zona posterioară, 45 de inlayuri din ceramică Vita Enamic. Ulterior, acestea au fost cimentate cu ciment adeziv Variolink II. Controalele periodice efectuate în vederea observării rezultatelor au fost realizate la 6, 12, 24 şi 36 luni, în conformitate cu criteriile modificate ale USPHS (United States Public Health Service). În urma studiului, a fost înregistrată o rată de succes de 97,4\%. A trebuit să fie refăcute trei restaurări, întrucât prezentau fracturi considerabile. După cei 3 ani de observare, nu au fost detectate carii secundare la nivelul dinţilor restauraţi. Fizionomia şi anatomia inlay-urilor au fost cotate ca fiind excelente (12).

Collares K. şi colaboratorii au condus un studiu amplu, în cadrul căruia 167 de practicieni au realizat 5.791 inlay-uri (ceramică cu matrice din sticlă), pe dinţii posteriori a 5.523 pacienţi, în perioada 1994-2014. Perioada medie de observare a fost de 3 ani, dar a atins şi un maximum de 15 ani. Rezultatele obţinute au arătat faptul că restaurările cu marginea cervicală situată în dentină au prezentat un risc de eşec cu 78\% mai mare decât în cazul restaurărilor cu margini în smalţ. De asemenea, s-a demonstrat faptul că prezenţa unei obturaţii de bază cu ciment ionomer de sticlă a condus la un risc de 
TABELUL 1. Detaliile celor 9 studii cercetate

\begin{tabular}{|c|c|c|c|c|c|c|c|c|}
\hline Referință & $\begin{array}{c}\text { Nr. de } \\
\text { pacienți }\end{array}$ & \begin{tabular}{|c|} 
Nr. de \\
incrustații
\end{tabular} & Ceramica utilizată & $\begin{array}{c}\text { Material de } \\
\text { cimentare }\end{array}$ & $\begin{array}{l}\text { Controale } \\
\text { periodice }\end{array}$ & $\begin{array}{l}\text { Nr. de } \\
\text { eşecuri }\end{array}$ & Cauzele eşecurilor & $\begin{array}{c}\text { Rata de } \\
\text { succes }\end{array}$ \\
\hline $\begin{array}{l}\text { Spitznagel F.A. şi } \\
\text { colab. }\end{array}$ & - & 45 & Vita Enamic & Variolink II & $\begin{array}{c}6,12,24 \\
36 \text { luni }\end{array}$ & 3 & Fractură & $97,4 \%$ \\
\hline Collares K şi colab. & 5523 & 5791 & $\begin{array}{c}\text { ceramică cu matrice } \\
\text { din sticlă }\end{array}$ & - & 3 ani & 220 & Fractură & $96,2 \%$ \\
\hline $\begin{array}{l}\text { Santos M.J. şi } \\
\text { colab. }\end{array}$ & 35 & 86 & $\begin{array}{l}\text { Duceram } \\
\text { IPS }\end{array}$ & Variolink II & $\begin{array}{c}1,2,3,5 \\
12 \text { ani }\end{array}$ & 13 & $\begin{array}{c}\text { Fractură } \\
\text { Carie secundară }\end{array}$ & $73 \%$ \\
\hline Beier U.S. şi colab. & 120 & 547 & $\begin{array}{c}\text { ceramică cu matrice } \\
\text { din sticlă }\end{array}$ & - & $\begin{array}{c}5,10 \\
12 \text { ani }\end{array}$ & 49 & Fractură & $91 \%$ \\
\hline $\begin{array}{l}\text { Borgia Botto E. şi } \\
\text { colab. }\end{array}$ & 47 & 93 & $\begin{array}{c}\text { ceramică cu matrice } \\
\text { din sticlă }\end{array}$ & - & 11 ani & 6 & Fractură & $93 \%$ \\
\hline Lange R.T. şi colab. & 109 & 264 & Evopress & - & 57 luni & 15 & - & $94 \%$ \\
\hline $\begin{array}{l}\text { Morimoto S. şi } \\
\text { colab. }\end{array}$ & - & 5811 & $\begin{array}{c}\text { Ceramic feldspatică/ } \\
\text { ceramică cu matrice } \\
\text { din sticlă }\end{array}$ & - & 5,10 ani & 348 & $\begin{array}{c}\text { Fractură } \\
\text { Complicații pulpare } \\
\text { Carie secundară }\end{array}$ & $94 \%$ \\
\hline $\begin{array}{l}\text { Christa D. Hopp şi } \\
\text { colab. }\end{array}$ & - & 296 & - & - & 9,12 ani & 31 & Fractură & $89,6 \%$ \\
\hline $\begin{array}{l}\text { Farahnaz } \\
\text { Nejatidanesh şi } \\
\text { colab. }\end{array}$ & 109 & 159 & $\begin{array}{c}\text { Cerec } \\
\text { Empress }\end{array}$ & - & 1, 5 ani & 7 & Fractură & $95,3 \%$ \\
\hline
\end{tabular}

degradare de două ori mai mare decât cel al restaurărilor fără material de obturaţie de bază. În cadrul studiului, au fost înregistrate 220 de eşecuri, iar motivul predominant a fost apariţia fracturilor la nivelul restaurării sau al dintelui, rata de succes înregistrată fiind astfel de 96,2\% (13).

Santos M.J. şi colaboratorii au realizat un studiu clinic ce a avut ca scop evaluarea clinică la 12 ani a celor 86 de incrustaţii ceramice, efectuate pentru 35 de pacienţi, cimentate cu material compozit cu priză duală. După 12 ani, s-au prezentat la evaluarea clinică doar 22 de pacienţi, fiind astfel analizate doar 48 de restaurări. În urma controlului clinic, s-au obţinut următoarele date: 7 incrustaţii au prezentat fracturi, 8 au prezentat carii secundare, 9 inlay-uri au prezentat defecte ale marginilor ce au necesitat înlocuire şi 4 au prezentat sensibilitate pulpară (14).

Beier U.S. şi colaboratorii au cimentat, în cadrul studiului clinic realizat, 547 de incrustaţii ceramice, în perioada 1987-2009, în cavităţile bucale a 120 pacienţi participanţi la studiu. Evaluarea clinică s-a realizat la 5, 10 şi 12 ani. În cazul onlay-urilor. s-a înregistrat, după 5 ani, o rată de succes de $98,9 \%$, dupa 10 ani, de $92,4 \%$ şi după 12 ani tot de $92,4 \%$. În cazul inlay-urilor s-a înregistrat o rată de succes de 98,9\% după 5 ani, de 96,8\% după 10 ani şi de 89,6\% după 12 ani. De asemenea, s-a mai observat faptul că dinţii devitali prezintă un risc sem- nificativ mai mare la eşec, faptul că restaurările realizate pe premolari au avut o rată de succes mai mare decât cele realizate pe molari (însă datele nu au fost semnificative din punct de vedere statistic) şi faptul că pacienţii diagnosticaţ̧i cu bruxism nu au prezentat o rată mai mare de eşec (15).

Borgia Botto E. şi colaboratorii au realizat un studiu clinic cimentând 93 de incrustaţii ceramice pe dinţii posteriori a 47 de pacienţi. După 11 ani, s-a înregistrat o rată de success de $93 \%$, ceea ce a condus către rezultate mulţumitoare (16).

Lange R.T. şi colaboratorii au studiat comportamentul clinic al inlay-urilor ceramice la 57 luni, respectiv 4 ani şi 9 luni de la cimentare. În perioada 2000-2003, au fost trataţi 109 pacienţi prin aplicarea a 250 de restaurări ceramice, realizate din ceramică Evopress. La reexaminare, au fost studiate 250 de incrustaţii, înregistrându-se astfel o rată de succes de 94\% (17).

Morimoto S. şi colaboratorii au realizat un studiu din literatură, cercetând articolele publicate în perioada 1983-2015. Rezultatele obţinute relevă o rată de succes a inlay-urilor ceramice de 94\% la controlul de 5 ani de la cimentare şi o rată de succes de $91 \%$ la controlul de 10 ani, fiind analizate un număr total de 5.811 restaurări ceramice la primul control, respectiv 2.154 inlay-uri la cel de-al doilea control. Studiul a mai concluzionat faptul că rata de succes nu pare să fie afectată de tipul materialului 
ceramic utilizat pentru realizarea incrustaţiilor (ceramică feldspatică/ceramică cu matrice din sticlă) sau de perioada dintre controalele clinice periodice (5 ani/10 ani). Eşecurile au fost determinate în cea mai mare parte de apariţia fracturilor, urmate, totuşi, îndeaproape de apariţia complicaţiilor pulpare şi, într-o măsură mai mică, de prezenţa cariilor secundare (18).

Christa D. Hopp şi colaboratorii au concluzionat o rată de succes de $89,6 \%$ a 296 de incrustaţii ceramice reexaminate la 9 , respectiv 12 ani. Principalul factor care a condus către eşecul restaurărilor este apariţia fracturii (19).

Farahnaz Nejatidanesh şi colaboratorii au cimentat 159 incrustaţii ceramice (102 realizate din blocuri de ceramică CEREC şi 57 realizate din blocuri de ceramică EMPRESS), tratând astfel 109 pacienţi, în perioada martie 2009 - septembrie 2009. Controalele clinice periodice au fost realizate la 1 an, respectiv 5 ani, evidenţiind o rată de succes de $96 \%$ pentru restaurările realizate din ceramică CEREC, respectiv o rată de succes de $94,6 \%$ pentru cele realizate din ceramică EMPRESS (20).

\section{DISCUŢII}

Studiul longevităţii restaurărilor dentare presupune monitorizarea lor pe perioade variate de timp cu cât perioada este mai mare, cu atât rezultatele sunt mai reprezentative.

În studiul prezent, în cele 9 studii conforme cu căutarea propusă, au fost urmărite 13.092 de incrustaţii ceramice. Deşi rata de succes este mai mare în cadrul studiilor ce au urmărit un timp mai scurt comportamentul inlay-urilor, media tuturor studiilor în ceea ce priveşte acest parametru este $91,5 \%$, ceea ce reprezintă un rezultat mulţumitor.

Cauza principală a eşecurilor înregistrate este reprezentată de prezenţa fracturilor, atât la nivelul restaurării, cât şi la nivelul ţesutului dentar remanent şi nu de apariţia cariilor secundare. S-a observat faptul că dimensiunea restaurării nu reprezintă un factor ce influenţează eşecul. De asemenea, longevitatea incrustaţiilor ceramice nu pare să fie dependentă de mărimea cavităţii.
Ideal ar fi ca pacienţii să fie înştiinţaţi de către medicul dentist în privinţa posibilităţii unui posibil eşec de 5-10\%, în cazul acestui tip de tratament.

Un factor important în succesul tratamentului dentar prin incrustaţii îl reprezintă avantajul tehnicilor adezive, eliminându-se astfel şi indicaţiile aplicării obturaţiilor de bază cu ciment glassionomer, întrucât s-a şi demonstrat că aceste obturaţii de bază nu reprezintă decât un factor în plus ce conduce către eşec.

Un alt parametru important în ceea ce priveşte longevitatea unei astfel de restaurări îl presupune cimentarea, practic, legătura dintre ţesutul dentar remanent şi restaurarea propriu-zisă.

Cimentarea poate fi influenţată de factori precum design-ul preparaţiei, tipul de răşină de cimentare ales, grosimea materialului şi tehnica de condiţionare a suprafeței dentinei, adică metoda de adeziune aleasă. Cimenturile răşinice le-au depăşit de mult pe cele ionomere de sticlă, puterea adeziunii actuale reprezentând un real succes în protetica dentară.

Materialele de cimentare răşinice cu priză duală au înregistrat rezultate mulţumitoare în studiile analizate în acest studiu. Studiile nu au arătat însă diferenţe semnificative din punct de vedere statistic, în ceea ce priveşte tipul de materiale ceramice utilizate.

În ultimul deceniu, evoluţia tehnologiei dentare a contribuit la dezvoltarea de tehnici şi materiale noi (21). Tehnologia CAD/CAM a revoluţionat în mod cert domeniul restaurator prin obţinerea unor rezultate superioare prin estetică, dar şi funcţionalitate. Tehnologia CAD/CAM a scurtat timpul procesului de fabricare a ceramicii cu până la 90\% (3).

\section{CONCLUZII}

Din examinarea studiilor din literatură reiese că incrustaţiile ceramice, realizate din tipuri diferite de ceramică şi cimentate cu material compozit cu priză duală, prezintă o longevitate acceptabilă, atât pentru medic, cât şi pentru pacient.

Conflict of interest: none declared Financial support: none declared 


\section{BIBLIOGRAFIE}

1. Petersen P.E. The World Oral Health Report 2003: Continuous Improvement of Oral Health in the 21st century The Approach of the WHO Global Oral Health Programme. Geneva: WHO; 2003.

2. Bagramian R.A., Garcia-Godoy F., Volpe A.R. The global increase in dental caries. A pending public health crisis. $A m \mathrm{~J}$ Dent 2009, 22:3-8.

3. Kim Li R.W. et al. Ceramic dental biomaterials and CAD/ CAM technology: State of the art. Journal of Prosthodontic Research 58.4 (2014): 208-216.

4. Deepak Viswanath, A. Vamsi Krishna Reddy. Biomimetics in dentistry - a review. Indian Journal of Research in Pharmacy and Biotechnology 2014 ISSN: 2321-5674.

5. Kelly J.R. Dental ceramics: current thinking and trends. Dent Clin North Am 2004 ;48(2): VIII, 513-530.

6. Denry I.L. Recent advances in ceramics for dentistry. Crit Rev Oral Biol Med 1996;7(2):134-143.

7. Kelly J.R. The clinical success of all-ceramic restorations The Journal of the American Dental Association. 2008 Sep;139.

8. Probster L., Geis-Gerstorfer J., Kirchner E., Kanjantra P. In vitro evaluation of a glass-ceramic restorative material. J Oral Rehabil 1997; 24(9): 636-45.

9. Ohyama T., Yoshinari M., Oda Y. Effects of cyclic loading on the strength of all-ceramic materials. Int J Prosthodont 1999; 12(1):28-37.

10. Christa D. Hopp, Martin F. Land. Considerations for ceramic inlays in posterior teeth: a review, Dove Press Journal: Clincal, Cosmetic and Investigational Dentistry 2013.

11. Sjögren G., Lantto R., Granberg A., Sundstrom B.O., Tillberg A. Clinical examination of leucite-reinforced glass-ceramic crowns (Empress) in general practice: a retrospective study. Int J Prosthodont 1999; 12(2):122-8.

12. Spitznagel F.A., Scholz K.J., Strub J.R., Vach K., Gierthmuehlen P.C., Polymer-infiltrated ceramic CAD/CAM inlays and partial coverage restorations: 3-year results of a prospective clinical study over 5 years. Clin Oral Investig. 2017 Dec 6.
13. Collares K., Corrêa MB., Laske M., Kramer E., Reiss B., Moraes R.R., Huysmans M.C., Opdam N.J. A practicebased research network on the survival of ceramic inlay/onlay restorations. Dent Mater. 2016 May; 32(5):687-94.

14. Santos M.J., Freitas M.C., Azevedo L.M., Santos G.C. Jr., Navarro M.F., Francischone C.E., Mondelli R.F. Clinical evaluation of ceramic inlays and onlays fabricated with two systems: 12-year follow-up Clin Oral Investig. 2016 Sep; 20(7):1683-90.

15. Beier U.S., Kapferer I., Burtscher D., Giesinger J.M., Dumfahrt H. Clinical performance of all-ceramic inlay and onlay restorations in posterior teeth. Int J Prosthodont. 2012 Jul-Aug; 25(4):395-402.

16. Borgia Botto E., Baró R., Borgia Botto J.L., Clinical performance of bonded ceramic inlays/onlays: A 5- to 18-year retrospective longitudinal study Am J Dent. 2016 Aug; 29(4):187-192.

17. Lange R.T., Pfeiffer P. Clinical evaluation of ceramic inlays compared to composite restorations. Oper Dent. 2009 May-Jun; 34(3):263-72.

18. Morimoto S., Rebello de Sampaio F.B., Braga M.M., Sesma N., Özcan M. Survival Rate of Resin and Ceramic Inlays, Onlays, and Overlays: A Systematic Review and Meta-analysis. J Dent Res. 2016 Aug; 95(9):985-94.

19. Christa D. Hopp, Martin F. Land. Considerations for ceramic inlays in posterior teeth: a review. Clin Cosmet Investig Dent. 2013; 5: 21-32.

20. Farahnaz Nejatidanesh, Mehrak Amjadi, Mohadese Akouchekian, Omid Savabi. Clinical performance of CEREC AC Bluecam conservative ceramic restorations after five years-A retrospective study. Journal of Dentistry 43 (2015) 1076-1082.

21. Lauvahutanon S. et al. Mechanical properties of composite resin blocks for CAD/CAM. Dental Materials Journal 33.5 (2014): 705-710. 